\title{
The protection and promotion of cultural diversity in a digital networked environment: Mapping possible advances towards coherence
}

\author{
MIRA BURRI-NENOVA, CHRISTOPH BEAT GRABER \\ AND THOMAS STEINER*
}

\section{KEY MESSAGES}

- Neither the WTO nor UNESCO currently offers appropriate solutions to the trade and culture predicament that would allow for efficient protection and promotion of cultural diversity.

- The trade and culture discourse is over-politicised and owing to the related path dependencies, a number of feasible solutions presently appear blocked.

- The digital networked environment has profoundly changed the ways cultural content is created, distributed, accessed and consumed, and may thus offer good reasons to reassess and readjust the present models of governance.

- Access to information appears to be the most appropriate focus of the discussions with a view to protecting and promoting cultural diversity in the new digital media setting, both in local and global contexts.

- This new focal point also demands broadening and interconnecting the policy discussions, which should go beyond the narrow scope of audiovisual media services, but cautiously take account of the developments at the network and applications levels, as well as in other domains, most notably protection of intellectual property rights.

- There are various ways in which the WTO can be made more conducive to cultural policy considerations and these include improved and updated services classifications; enhanced legal certainty with regard to digitally transferred goods and services; and incorporation of rules on subsidies for services and on competition.

\footnotetext{
* Individual Project No. 7, 'eDiversity: The Protection of Cultural Diversity in a Digital Networked Environment'. Thanks for insightful comments are owed to Manfred Elsig, Thomas Messerli, Thomas Cottier and Panagiotis Delimatsis.
} 


\section{A. Introduction}

Cultural diversity as a concept and as a distinct public policy objective has substantially gained in significance in the past decade and its role is likely to be augmented in the years to come. While there is no single understanding of what cultural diversity is, and perhaps fortunately so, we have observed the emergence of a clear set of policy choices and decisions at all levels of governance that could be subsumed under this rather novel public policy goal. Particularly interesting have been the developments at the international level because of the battle - intrinsic to economic globalisation - between 'trade' and 'non-trade' values, of which cultural diversity is one. The trade and culture quandary has also been intriguing because of its political charge and because the cultural proponents have been successful in forum-shifting cultural policy matters (at least partially) from the World Trade Organization (WTO) to the United Nations Educational, Scientific and Cultural Organization (UNESCO). Adding a level of complexity to these discussions, but also offering exciting challenges and possibilities for reform, is the fact that the regulatory environment, where any trade and culture debate is to be resolved, has been profoundly changed due to the advent and wide spread of digital technologies.

It is the purpose of this chapter to account for these changes in the global media landscape and while recalling the main tenets of the trade and culture discourse, to advance proposals for its reformulation. We conjecture that there is no 'one-size-fits-all' solution to the trade and culture predicament but many that need to be coherently fitted together. The digital networked environment that utterly transforms the ways in which cultural content is produced, distributed, accessed and consumed, has potentially also created a number of opportunities to abandon (as far as politically possible) the current strong path dependencies, to reassess and to amend the international trade rules accordingly, making them more conducive to the pursuit of domestic cultural policies, while at the same time avoiding blatant protectionism. The international community may also need to take into account a host of new issues that are emergingissues that require additional regulatory intervention in order to ensure a sustainable and thriving cultural environment.

\section{B. The discourse of trade and culture}

The discourse of trade and culture at the international level is an example par excellence of fragmented regulatory regimes. Many institutions 
and organisations (e.g. WTO, UNESCO, the World Intellectual Property Organization (WIPO); the World Summit on the Information Society (WSIS); and the International Telecommunications Union (ITU)) adopt rules of both a hard and a soft nature that affect cultural diversity to different degrees, and these decisions are taken without any meaningful coordination or even any attempt at dialogue between them. Multiple decisions with strong impact and spill-over effects are also taken at the regional, bilateral and domestic levels. To reduce this complexity and going back to the original roots of the trade and culture predicament, we reconstruct it primarily in the framework of the WTO and that of UNESCO. ${ }^{1}$

The discussions on the relationship between trade and culture started in a context of international trade after World War I when the initial predominance of European cinema came to an end and Hollywood was established as the new centre of global filmmaking. ${ }^{2}$ As a reaction to this shift of power, many European governments introduced measures to protect their domestic film industries, including import and screen quotas. The US State Department coming to the aid of Hollywood exerted pressure on European governments to overturn the protective measures. Both antagonists were relieved when in 1947 the newly established General Agreement on Tariffs and Trade (GATT) managed to provisionally resolve the conflict. ${ }^{3}$ With the emergence and wide spread of television as a lucrative mass medium in the second half of the twentieth century, European and Canadian airtime quotas for domestic television programmes fuelled the debate anew. The flexibility mechanisms introduced after the Uruguay Round under the auspices of the newly founded WTO in 1994 only managed to put the conflict on ice rather than providing for an enduring solution. No such solution is anticipated in the Doha Trade Talks either.

Interestingly, it was only in the 1990s that UNESCO took a concrete interest in protecting cultural diversity from the alleged negative effects of

1 C. B. Graber, 'The New UNESCO Convention on Cultural Diversity: A Counterbalance to the WTO?' (2006) 9 Journal of International Economic Law 553, p. 554.

2 N. Gabler, An Empire of Their Own: How the Jews Invented Hollywood (New York: Anchor, 1988); R. Sklar, Film: An International History of the Medium (Upper Saddle River, NJ: Prentice Hall, 1993), p. 95.

3 The GATT prohibited quantitative restrictions on imports in Article XI GATT but provided for an exception from the obligation of national treatment for cinematograph films in Articles III(10) and IV GATT. See C. B. Graber, Handel und Kultur im Audiovisionsrecht der WTO (Bern: Staempfli, 2003), pp. 125-128. 
international trade and economic globalisation, ${ }^{4}$ and in this way one can clearly discern the pattern of conflict in the matters of trade and culture (in this sense, often framed as 'trade versus culture'). Key steps in this process were the publication of the seminal report 'Our Creative Diversity' by the World Commission on Culture and Development in 1995 and the 1998 Stockholm Conference on Cultural Policies for Development, recommending, inter alia, a recognition that cultural goods and services should be 'treated as being not like any other form of merchandise. ${ }^{5}$ In November 2001, UNESCO adopted a non-binding declaration on cultural diversity and on 18 March 2007, the binding UNESCO Convention on the Protection and Promotion of the Diversity of Cultural Expressions entered into force ${ }^{6}$ as a culmination of these efforts.

In the next section, we look in more detail into the respective frameworks of the WTO, in particular at the rules applicable to trade in goods and services, and of UNESCO, in particular at the legal and policy impact of the UNESCO Convention on Cultural Diversity. We expose the lack of appropriate solutions catering for cultural diversity protection and promotion in both of these fora, which offers fruitful soil for suggesting new perspectives, adjustments and reforms.

\section{Incompleteness of the trade and culture discourse \\ I. The WTO framework}

As already noted, the GATT 1947 provided for a provisional solution to the film dispute between the US and Europe by conceding screen quotas in Article IV GATT while prohibiting import quotas for films pursuant to Article XI GATT. Over time, screen quotas have lost much of their practical significance and South Korea is probably the only state left that still insists on this instrument for assuring a strong presence of domestic films on cinema screens. ${ }^{7}$ Besides the leeway for screen quotas expressly

4 I. Bernier, 'A UNESCO International Convention on Cultural Diversity', in C. B. Graber, M. Girsberger and M. Nenova (eds.), Free Trade versus Cultural Diversity: WTO Negotiations in the Field of Audiovisual Services (Zurich: Schulthess, 2004), pp. 65-76, p. 72.

5 See Objective 3, para. 12 of the Action Plan adopted at the Stockholm Conference.

6 UNESCO, Convention on the Protection and Promotion of the Diversity of Cultural Expressions, adopted 20 October 2005, entry into force 18 March 2007. For a detailed discussion of this process, see Graber, above n. 1, pp. 556-558.

7 After the US made the conclusion of a free trade agreement contingent on the partial abolishment of the screen quota scheme, South Korea halved the requirement for exhibitors to screen Korean films as of 1 July 2006 from $40 \%$ to $20 \%$ of the total screening time. Today 
devised in Article IV GATT, plenty of other norms scattered throughout the body of the WTO law can be found relevant and allow some flexibility as far as trade in cultural goods and services is concerned. ${ }^{8}$ In particular, the General Agreement on Trade in Services (GATS) offers more wiggle room than the GATT, ${ }^{9}$ since the GATS framework involves primarily a 'bottom-up' (or 'positive list') approach. Thereby Members can choose the services sectors and sub-sectors in which they are willing to make national treatment or market access commitments, ${ }^{10}$ and can define the modalities of these commitments. In contrast, obligations under GATT regarding national treatment and quantitative restrictions apply across the board, subject to specified exceptions.

The scope for domestic measures regarding trade in culture was however never found sufficient. ${ }^{11}$ The inner tension between trade and culture has always been there, even within the GATT 1947, the WTO's less far-reaching institutional predecessor. ${ }^{12}$ This tension led to an explosion during the Uruguay Round (1986-1994), when France and Canada fought the 'exception culturelle' battle with the goal of exempting cultural services (in particular audiovisual ones) from the newly created agreement on services. ${ }^{13}$ The infamous 'Agreement to Disagree' was a sort of ceasefire in the trade versus culture quandary. Thereby, it was established

Korean cinemas have to screen locally produced films for 73, rather than the 146 days necessary under the previous regime. See W. Choi, 'Screen Quota and Cultural Diversity: Debates in Korea-US FTA Talks and Convention on Cultural Diversity' (2007) 2 Asian Journal of WTO and International Health Policy 267.

8 For an overview of all relevant provisions, see C. B. Graber, 'Audiovisual Media and the Law of the WTO', in Graber et al., above n. 4, pp. 47-56.

9 Graber, above n. 1, pp. 555 and 569.10 Articles XVI and XVII GATS.

11 S. Cahn and D. Schimmel, 'The Cultural Exception: Does it Exist in GATT and GATS Frameworks? How Does It Affect or Is It Affected by the Agreement on TRIPS? (1997) 15 Cardozo Arts and Entertainment Law Journal 281, pp. 287-289.

12 See e.g. GATT, EEC-Directive on Transfrontier Television: Response to Request for Consultations under Article XXVII:I by the United States, DS4/4, 8 November 1989. Later WTO cases worth mentioning are WTO, Turkey - Taxation of Foreign Film Revenues: Request for Consultations by the United States, WT/DS43/1, 17 June 1996; WTO, Turkey - Taxation of Foreign Film Revenues: Request for Establishment of a Panel by the United States, WT/DS43/2, 10 January 1997; WTO Panel Report, Canada - Certain Measures Concerning Periodicals (Canada - Periodicals), WT/DS31/R and Corr.1, adopted 30 July 1997, as modified by the Appellate Body Report, WT/DS31/AB/R, DSR 1997:I, 48114 March 1997 and WTO Appellate Body Report, Canada - Certain Measures Concerning Periodicals (Canada-Periodicals), WT/DS31/AB/R, adopted 30 July 1997, DSR 1997:I, 449WT/DS31/AB/R, adopted 30 June 1997.

13 See C. B. Graber, 'Audio-visual Policy: The Stumbling Block of Trade Liberalisation', in D. Geradin and D. Luff (eds.), The WTO and Global Convergence in Telecommunications and 
that GATS covers all services sectors but permits substantial commitment flexibilities. ${ }^{14}$ Taking advantage of these, many states had listed no or only minimum commitments with regard to national treatment and market access and exempted sensitive sectors (in particular audiovisual services) from most-favoured-nation (MFN) obligations. ${ }^{15}$

However, the 'Agreement to Disagree' was not a real solution and cultural proponents were well aware of this. The further liberalisation commitment ${ }^{16}$ was impending and the MFN exemptions made were at least theoretically limited in time. ${ }^{17}$ A particularly hard blow to the backers of the cultural exception was the Canada-Periodicals case, ${ }^{18}$ decided by the Panel and the Appellate Body to the benefit of the US and despite the fact that the Canada-US Free Trade Agreement (CUSFTA) ${ }^{19}$ envisaged a cultural exception clause. ${ }^{20}$ Furthermore, as Canada-Periodicals showed exemplarily, the system of exceptions to GATT obligations, including the

Audiovisual Services (Cambridge University Press, 2004), pp. 165-214; M. Roy, 'Audiovisual Services in the Doha Round: Dialogue de Sourds, The Sequel?' (2005) 6:6 Journal of World Investment and Trade 923, p. 941.

14 See C. M. Bruner, 'Culture, Sovereignty, and Hollywood: UNESCO and the Future of Trade in Cultural Products' (2008) 40 International Law and Politics 351, p. 374; F. S. Galt, "The Life, Death, and Rebirth of the "Cultural Exception" in the Multilateral Trading System: An Evolutionary Analysis of Cultural Protection and Intervention in the Face of American Pop Culture's Hegemony' (2004) 3:3 Washington University Global Studies Law Review 909, p. 914; Cahn and Schimmel, above n. 11, pp. 291-301.

15 Almost all Members, with the notable exception of the US, Japan and New Zealand, have been reluctant to commit and have listed substantial MFN exemptions. See Roy, above n. 13 , p. 927.

16 See Part IV GATS. Article XIX therein states: 'In pursuance of the objectives of this Agreement, Members shall enter into successive rounds of negotiations, beginning not later than five years from the date of entry into force of the WTO Agreement and periodically thereafter, with a view to achieving a progressively higher level of liberalization.'

17 The GATS Annex on Article II Exemptions states (para. 6) that, '[i]n principle, such exemptions [to MFN] should not exceed a period of 10 years. In any event, they shall be subject to negotiation in subsequent trade liberalizing rounds.' The exemptions made theoretically expired in 2005.

18 See above n. 12.

19 Canada-US Free Trade Agreement, 22 December 1987-2 January 1988, 27 ILM 281 (1988).

20 In CUSFTA, the culture exception was coupled with a retaliation provision. Article 2005 CUSFTA provides that, '[c]ultural industries are exempt from the provisions of this Agreement', but also that either party could 'take measures of equivalent commercial effect in response to [such] actions'. The North American Free Trade Agreement (NAFTA; 17 December 1992, 32 ILM 289 (1993)) incorporated by reference to CUSFTA this cultural exception. It exists only between Canada and both the US and Mexico, but not between the US and Mexico. In practice, this provision offering comfort to the Canadian cultural sector had little effect. See Cahn and Schimmel, above n. 11, p. 30. 
general exceptions provided by Article XX GATT, does not sufficiently respond to cultural concerns in domestic policy making. ${ }^{21}$ The only provision available for cultural issues is Article XX(f) GATT providing for an exception to GATT disciplines for the protection of 'national treasures of historic, artistic, or archaeological value'. However, this concept does not include artefacts of contemporary creative production. ${ }^{22}$ Following the design of GATT, the GATS' general exceptions ${ }^{23}$ to the obligations of national treatment, market access and MFN fall short of providing for a safeguard for cultural diversity purposes.

Moreover, because of the deadlock in negotiations, neither the GATT nor the GATS has been substantially updated as far as the modalities of committing are concerned. In particular, the existing GATS nomenclature for services classification (the W/120 with reference to the United Nations Central Product Classification $(\mathrm{CPC})^{24}$ ) has been outpaced by the rapid technological developments of the past few years. It has not adapted to the digital turn, which has profoundly changed the ways in which audiovisual media are created, produced, distributed and consumed and is ill-prepared to appropriately classify a number of new services associated with electronic commerce. ${ }^{25}$

To exemplify this lack of appropriate and up-to-date responses in WTO law, we discuss here the instance of digital games. Digital games, in particular in their online versions, are increasingly becoming not only a major attraction for the new generation of media consumers but also an important economic and cultural asset. Governments have been assuming that certain types of digital games are a form of cultural expression and have put in place support programmes for the production of new games. ${ }^{26}$

21 Although Canada argued, inter alia, that the disputed customs tariff discriminating splitrun periodicals was necessary for protecting the Canadian periodicals industry and cultural policy goals, the WTO dispute settlement authorities did not consider this to be an issue of Article XX(f) GATT. See above n. 12.

22 Graber, above n. 1, p. 568.23 See Article XVI GATS.

24 WTO, Services Sectoral Classification List, WTO Doc.MTN.GNS/W/120, 10 July 1991, referring to UN Provisional Central Product Classification (CPC), UN Statistical Papers, Series M, No 77, Ver.1.1, E.91.XVII.7, 1991. The classification problem is similar for goods and the applied Harmonized System, created and regularly amended by the World Customs Organization. See D. Yu, 'The Harmonized System: Amendments and Their Impact on WTO Members' Schedules' (2008) WTO Economic Research and Statistics Division Staff Working Paper No. 2, pp. 1-23.

25 Graber, above n. 13, pp. 208-209.

26 For a detailed analysis, including examples for government support programmes, see C. B. Graber, 'State Aid for Digital Games and Cultural Diversity: A Critical Reflection in the Light of EU and WTO Law', in C. B. Graber and M. Burri-Nenova (eds.), Governance 
From a trade law perspective, however, these media are under conditions of legal uncertainty. It stems above all from the difficulty of classifying digital games into a certain category of goods or services. Such a classification is related to distinct (and often starkly different) legal consequences (in particular with regard to the leeway a state may have to adopt for targeted cultural measures), because of the different depth of liberalisation under GATT or GATS, and because of the uneven commitments for different types of services under the GATS.

While ideally the classification of digital games between GATT and GATS should be resolved through political consensus, such a decision is currently not anticipated, mostly because of the diverging positions of the US and the EU. ${ }^{27}$ While awaiting such an agreement, the fact that the GATT does not provide a tariff number for digital games' content may be an indication for a GATS classification. ${ }^{28}$ However, even if GATS appears applicable, it is unclear whether the appropriate sub-classification is that of computer and related services; value-added telecommunications services; entertainment; or audiovisual services ${ }^{29}$ (which are further divided into more sub-categories). ${ }^{30}$

\section{The UNESCO Convention on Cultural Diversity}

Only a couple of years after its entry into force almost 100 countries had ratified the UNESCO Convention on Cultural Diversity

of Digital Game Environments and Cultural Diversity (Cheltenham: Edward Elgar, 2010), pp. 170-201.

27 M. Burri-Nenova, 'Trade versus Culture in the Digital Environment: An Old Conflict in Need of a New Definition' (2009) 12 Journal of International Economic Law 17, pp. 52-54.

28 Whereas the physical carrier medium on which digital games' software is stored may be classified under either Heading 85.24 or 9504.10 , the HS does not seem to provide for a classification for the digital games' content itself. See T. Steiner, 'Online Games under WTO Law: Unresolved Classification Issues' (2009) NCCR Trade Regulation Working Paper 2009/3 pp. 13-15.

29 S. Wunsch-Vincent, The WTO, the Internet and Trade in Digital Products (Oxford: Hart, 2006), p. 71.

30 In this regard, we would tend to nominate audiovisual services in particular the subcategory of 'other' as the most relevant since this is most likely to reflect the essential character of the digital games as a multimedia service. The classification of digital games as GATS 'other' audiovisual services would have important implications for the treatment of digital games as presumably cultural products. In view of the low level of commitments in the audiovisual services sub-sector, it may be established that existing obligations of the WTO agreements do not seem to prevent governments from supporting the development and production of digital games. See Steiner, above n. 28, and Graber, above n. 26. 
(CCD). ${ }^{31}$ Whereas the ratification process is a success and an important precondition for the CCD being able to play its intended role as a counterbalance to the WTO, it cannot disguise the serious flaws that disturb the beauty of the new instrument.

The CCD builds on two cornerstones. The first is the recognition of the cultural sovereignty of the Parties, encompassing the right to adopt measures on cultural policy. ${ }^{32}$ The second is the recognition of the dual nature of cultural goods and services as objects of trade and as cultural artefacts. ${ }^{33}$ Since cultural goods and services are not only objects of trade but have a distinctive cultural nature as 'vehicles of identity, values and meaning, ${ }^{34}$ the CCD calls upon governments to take appropriate measures to adjust imbalances in the relationship between trade and culture. The CCD provides no explicit definition of culture but rather adopts a discursive approach to culture, referring to 'the manifold ways in which the cultures of groups and societies find expression. ${ }^{35}$ Hence, this definition permits one to analyse cultural diversity in terms of the markets where it is represented. As the discursive approach to cultural diversity opens the door for statistical measurement and for political economic analysis, it has been considered to be an important contribution towards rationalising the debate on trade and culture at the international level. ${ }^{36}$ This positive aspect of the CCD is, however, nearly nullified by the fact that most of its provisions - including those in its core chapter IV on rights and obligations - are rather fuzzy. ${ }^{37}$ The UNESCO Convention has precious few obligations and these are primarily formulated as mere stimuli for the Parties to adopt measures for the protection and promotion of the diversity of cultural expressions at the national ${ }^{38}$ and international ${ }^{39}$ levels, rather than as genuine duties. ${ }^{40}$ The only provision of binding

31 As of 2 July 2009, 99 countries had ratified the UNESCO Convention (see http://portal.unesco.org/la/convention.asp? $\mathrm{KO}=31038 \&$ language $=\mathrm{E}$; last accessed 29 July 2009).

32 Article 5 CCD. 33 Recital 18 of the Preamble and Article 1(g) CCD.

34 Article 1(g) CCD. 35 Article 4 CCD. 36 Graber, above n. 26.

37 For a detailed analysis see C. B. Graber, 'Substantive Rights and Obligations under the UNESCO Convention on Cultural Diversity', in H. Schneider and P. van den Bossche (eds.), Protection of Cultural Diversity from an International and European Perspective (Mortsel: Intersentia, 2008), pp. 141-162.

38 CCD, at Articles 7-11.

39 CCD, at Articles 12-19, excluding Article 16, which is of binding nature.

40 Graber, above n. 37, p. 6. 
nature $^{41}$ resembles the WTO's Enabling Clause ${ }^{42}$ and relates to the preferential treatment for developing countries, whereby developed countries must facilitate cultural exchanges with developing countries by granting preferential treatment to artists and other cultural professionals and practitioners, as well as to cultural goods. ${ }^{43}$ The fuzziness of many provisions ${ }^{44}$ and the limited obligations make the CCD vulnerable to accusations of being an instrument of protectionism.

A further shortcoming is related to the centrality of state sovereignty which is intrinsic to the CCD. Indeed, the sovereignty of the State Parties in the cultural field is included as one of the eight guiding principles underpinning the Convention (Article $2(2)^{45}$ ) and all rights and obligations stemming from the Convention are attributed to states. This is particularly disturbing with regard to the relationship between indigenous peoples and the governments of the territory where they live. While the Convention does mention indigenous peoples and traditional cultural expressions a few times, ${ }^{46}$ the relevant provisions remain declarative in nature and address not the rights of the indigenous peoples themselves but those of the states whose territory is affected. Consequently, the CCD does not respect the rights of indigenous peoples for cultural self-determination and self-governance, which are the

$41 \mathrm{Ibid}$. p. 8 , footnote 59. Another provision that qualifies as an obligation relates to the cooperation in providing assistance, in particular to developing countries, in situations of serious threat to cultural expressions (Article 17 CCD). Burri-Nenova, above n. 27, p. 22.

42 See GATT, Decision of 28 November 1979 (L/4903), Differential and More Favourable Treatment, Reciprocity and Fuller Participation of Developing Countries ('Enabling Clause'). See also B. Hoekman, 'More Favorable Treatment of Developing Countries: Ways Forward', in R. Newfarmer (ed.), Trade, Doha, and Development: Window into the Issues (Washington, DC: World Bank, 2006), pp. 213-221; S. W. Chang, 'WTO for Trade and Development Post-Doha' (2007) 10 Journal of International Economic Law 553.

43 CCD, at Article 16; Burri-Nenova, above n. 27, p. 22. On the probably limited effect of Article 16 CCD, see K. Nurse, Expert Report on Preferential Treatment (Article 16) in the UNESCO Convention on the Protection and Promotion of the Diversity of Cultural Expressions, 10 October 2008, p. 24.

44 H. Ruiz Fabri, 'Reflections on Possible Future Legal Implications of the Convention', in N. Obuljen and J. Smiers (eds.), UNESCO's Convention on the Protection and Promotion of the Diversity of Cultural Expressions: Making It Work (Zagreb: Institute for International Relations, 2006), pp. 73-87, p. 80.

45 Burri-Nenova, above n. 27, p. 25. See also R. Craufurd Smith, 'The UNESCO Convention on the Protection and Promotion of Cultural Expressions: Building a New World Information and Communication Order?' (2007) 1 International Journal of Communication 24, p. 37.

46 CCD, Preamble at recitals 8, 13 and 15, Articles 2(3) and 7(1)(a). 
fundament of the recently adopted Declaration of the United Nations on the Rights of Indigenous Peoples. ${ }^{47}$ Finally, the CCD falls short of clarifying its relationship to the international system of intellectual property rights protection, ${ }^{48}$ which is deplorable, since, as we show below, intellectual property rights play a vital role in promoting and sustaining creativity.

This innate defect of normative incompleteness of the CCD is aggravated by the lack of institutional or adjudicatory mechanisms that could procedurally clarify and complete the contract. The Convention's exponents still hope that the Intergovernmental Committee and the Convention's own dispute resolution will fill some of the existing gaps, since both allow evolutionary advances, depending upon the willingness of the Parties. It should be noted however that the dispute settlement is ultimately not compulsory ${ }^{49}$ and the tasks of the Intergovernmental Committee, as defined in Article 23(6) CCD, may not provide a solid legal basis for it to engage in interpretation of the Convention beyond commenting on the State Parties' reports. ${ }^{50}$

Against the above backdrop, it is evident that neither of the institutional domains of the trade and culture discourse, i.e. the WTO and UNESCO, provide appropriate solutions for the underlying trade-culture quandary. Nor do they ensure a workable interface between the two regimes, as the recent China - Publications and Audiovisual Products case confirmed. ${ }^{51}$ What is instead observable is a continuing disconnect between the issues of trade and culture, which has been strongly politically driven and

47 The Declaration was adopted on 13 September 2007. See UN General Assembly, 'General Assembly Adopts Declaration on Rights of Indigenous Peoples', Press Release GA/10612, 13 September 2007.

48 Burri-Nenova, above n. 27, pp. 55-58.

49 See M. Hahn, 'A Clash of Cultures? The UNESCO Diversity Convention and International Trade Law' (2006) 9 Journal of International Economic Law 515, p. 533, who critically remarks that the UNESCO Convention's dispute settlement is 'worth mentioning only as being reminiscent of the very early days of modern international law'.

50 See Article 23(6)(c) CCD.

51 WTO Appellate Body Report, China - Measures Affecting Trading Rights and Distribution Services for Certain Publications and Audiovisual Entertainment Products (China - Publications and Audiovisual Products), WT/DS363/AB/R, adopted 21 December 2009, confirming in most essential points WTO Panel Report, China - Measures Affecting Trading Rights and Distribution Services for Certain Publications and Audiovisual Entertainment Products (China - Publications and Audiovisual Products), WT/DS363/R, adopted 12 August 2009. For an analysis, see M. Burri, 'Trade and Culture in International Law: Paths to (Re)conciliation' (2010) 44 Journal of World Traded 49. 
widely accepted but which may obstruct the formulation of coherent solutions. ${ }^{52}$

\section{Need to broaden the picture due to the new digital reality}

The above system of institutional and substantive relationships between issues of trade and culture emerged under the conditions of analogue/ offline media. The hornets' nest in these developments has primarily been around audiovisual media and the diverse measures that states have adopted to protect and promote the national industries producing them. ${ }^{53}$ Such initiatives have been politically strengthened by the perceived adverse effects of globalisation, in particular upon culture, ${ }^{54}$ as well as by the presumption that technological advances negatively affect the diversity of cultural expressions and demand more rather than less regulatory intervention. ${ }^{55}$

The media landscape has however not remained static and in the past two decades has experienced profound changes, which have led to a decidedly different information and communication environment. ${ }^{56} \mathrm{We}$ argue that under these new conditions, whose salient features will be sketched here, ${ }^{57}$ there is a need to broaden the trade and culture debate and seek a new focal point of these deliberations that more appropriately

52 M. Burri-Nenova, 'Trade and Culture: Making the WTO Legal Framework Conducive to Cultural Considerations' (2008) 5 Manchester Journal of International Economic Law 3.

53 The underlying 'axioms' of state intervention have been that some sort of additional regulation is needed because of the failures inherent to media markets and that these market failures can be corrected through state measures. Failures typical of the markets for cultural goods and services can be identified as failures due to: (i) economies of scale in production and distribution; (ii) the nature of competition in products with substantial public goods aspects; (iii) the impact of externalities on the pricing of cultural products; and (iv) collective action problems. See P. Sauvé and K. Steinfatt, 'Towards Multilateral Rules on Trade and Culture: Protective Regulation or Efficient Protection?', in Productivity Commission and Australian National University, Achieving Better Regulation of Services (AusInfo, 2000), pp. 323-346, p. 325.

54 Against such undifferentiated arguments, see A. Giddens, Runaway World: How Globalisation Is Reshaping Our Lives (Oxford: Routledge, 2002), p. xxiv. See also T. Cowen, Creative Destruction: How Globalization Is Changing the World's Cultures (Princeton, NJ: Princeton University Press, 2002), p. 146 and T. Cowen, In Praise of Commercial Culture (Cambridge, MA: Harvard University Press, 1998), pp. 15-43.

55 For a discussion, see Graber, above n. 1, p. 570.

56 Y. Benkler, The Wealth of Networks: How Social Production Transforms Markets and Freedom (New Haven, CT: Yale University Press, 2006), p. 2.

57 For a full analysis, see M. Burri-Nenova, 'The Changing Environment of Audiovisual Media: New Technologies, New Patterns of Consumer/Business Behaviour and Their Implications for Audiovisual Media Regulation' (2007) 12 medialex 171. 
reflects the changed reality of media. Translating this into the policy space may also demand a re-evaluation of the policy tools for the achievement of the objective of cultural diversity.

At the core of the sweeping changes on the media canvas is the process of digitisation, which enables any type of information (be it text, audio, video, or image) to be expressed in a line of zeroes and ones. This coded data can also be easily stored and transported at the speed of light, and this, as the experience of the past fifteen years shows, takes place at an ever decreasing price. ${ }^{58}$ This basic matrix combined with the wide spread of optical fibre networks and exponentially increasing computational power, has led to a variety of transformations in the information and communications environment, which have become palpable in different facets of societal practices. Filtering in context these transformations, we can identify as particularly relevant: (i) the proliferation and diversity of content; (ii) its accessibility; (iii) the empowerment of the user; and (iv) the new modes of content production, where the user is not merely a consumer but is also an active creator, individually or as part of the community. While some of these developments are still in their infancy, they are already entering a phase that permits observations of immediate relevance for the discussion on protecting and promoting cultural diversity. Some of these observations hint at opportunities for better, more efficient and flexible accommodation of the goal of cultural diversity, while others are to be viewed as challenges, perhaps calling for additional regulatory intervention.

In the latter category, one may list the anticipated drastically fragmented media environment, as content consumption moves from a 'push' to a 'pull' mode (i.e. from broadcasting to on-demand). ${ }^{59}$ The split between digital and analogue households, which is already a reality, will also be exacerbated, and while this widening gap between the digital 'haves' and 'have-nots' is noticeable within developed societies, it is all the more striking between the developed and the developing and least developed societies. ${ }^{60}$ In terms of competition, the effects of the digital

58 See e.g. C. Marsden et al., Assessing Indirect Impacts of the EC Proposals for Video Regulation (RAND Europe, 2006), pp. $72 \mathrm{ff}$.

59 J. Naughton, 'Our Changing Media Ecosystem', in E. Richards et al. (eds.), Communications: The Next Decade (Ofcom, 2006), pp. 41-50. See also D. Graham et al., Impact Study of Measures Concerning the Promotion of Distribution and Production of TV Programmes Provided for under Article 25(a) of the TV without Frontiers Directive, Final Report prepared for DG Information Society, 2005, at section 3.5.1.

60 E. S. Nwauche, 'African Countries' Access to Knowledge and the WIPO Digital Treaties' (2005) 8 Journal of World Intellectual Property 361. 
networked environment are multi-directional. On the positive side, it is conceivable that the reduced barriers to entry will allow new market players to position themselves and make use of niche markets, which have become economically viable in the digital ecosystem due to the dramatically falling storage, distribution and search costs (the so-called 'long tail' effect $\left.{ }^{61}\right)$. The digital setting may also have reduced the significant entrepreneurial risk inherent in launching new cultural goods and services $^{62}$ (at least for some of them), while making the visibility of cultural goods and services greater and empowering the consumer in terms of choice and actual consumption.

On the other hand, a concentration among the diverse players in media markets, both horizontally and vertically, may also be expected, because of their pursuit of better utilisation of all available channels and platforms ${ }^{63}$ and the related benefits from economies of scale worldwide. The development of truly ubiquitous global market players may have a number of grave effects upon cultural diversity, among others, certainly leading to magnified importance of a very small number of languages (in particular English). Nonetheless, the digitally facilitated abundance of content, its dissemination and accessibility without real location restrictions undoubtedly lead to more content and to new content ${ }^{64}$ being generated and spread individually or by groups. ${ }^{65}$ Some of this user created content (UCC) reflects the key media policy components of diversity,

61 See C. Anderson, The Long Tail: Why the Future of Business Is Selling Less of More (New York: Hyperion, 2006). The name 'long tail' has to do with the image of a demand curve that gets longer and longer and covers more and more niche 'non-hit' products. Anderson's theory builds upon previous and parallel economic research. See E. Brynjolfsson, Y. Hu and M. D. Smith, 'From Niches to Riches: The Anatomy of the Long Tail' (2006) 47 Sloan Management Review 67; E. Brynjolfsson, Y. Hu and D. Simester, 'Goodbye Pareto Principle, Hello Long Tail: The Effect of Search Costs on the Concentration of Product Sales', MIT Center for Digital Business Working Paper (2007).

62 Germann argues that this specificity of cultural goods and services is the main issue that commands intervention. See C. Germann, 'Culture in Times of Cholera: A Vision for a New Legal Framework Promoting Cultural Diversity' (2005) 6 ERA-Forum 109, p. 116.

63 For instance, by placing a single video on mobile and digital TV networks, on content platforms and social networking websites such as YouTube, MySpace and Facebook.

64 D. Weinberger, Everything Is Miscellaneous (New York: Henry Holt, 2007) and OECD, Participative Web: User-Created Content, DSTI/ICCP/IE(2006)7/FINAL, 12 April 2007.

65 'Changes in the way users produce, distribute, access and re-use information, knowledge and entertainment potentially give rise to increased user autonomy, increased participation and increased diversity. These may result in lower entry barriers, distribution costs and user costs and greater diversity of works as digital shelf space is almost limitless.' OECD, ibid., p. 5. 
localism and non-commercialism ${ }^{66}$ and in this sense harnessing the UCC processes could be critical for achieving cultural diversity objectives. ${ }^{67}$ Beyond these 'amateur' creations, ${ }^{68}$ the digital environment has also had a strong impact upon how artists and culture-makers express themselves, how they communicate with one another and with the public, how cultural content is presented and made accessible and how it is consumed. In short, digitisation, both as a tool of expression and as a new cultural communication space 'affects the entire spectrum of culture production, distribution and presentation... [and] brings with it the promise of cultural renewal. ${ }^{69}$

The new dynamics of the markets for digital cultural content may also impact upon the market failures conventionally associated with 'analogue' media markets, mostly because of the changed notion of scarcity in the digital space. In this context, the idea of protecting some 'shelf-space' for culturally or nationally distinctive productions makes little sense since the 'shelf-space' is virtually unlimited. Furthermore, it may also become impossible to 'reserve' space for a certain purpose, since it is the consumer herself or himself who decides about the content, its form and time of delivery.

\section{E. Access as a new focal point of the cultural diversity debate}

Following the above arguments, one may legitimately question any cultural policy measure that restricts trade by putting up barriers to incoming foreign cultural goods and services. ${ }^{70}$ One may also have reservations

66 E. P. Goodman, 'Media Policy Out of the Box: Content Abundance, Attention Scarcity, and the Failures of Digital Markets' (2004) 19 Berkeley Technology Law Journal 1389, pp. 1395-1399.

67 For a specific analysis of UCC in virtual worlds, see M. Burri-Nenova, 'User Created Content in Virtual Worlds and Cultural Diversity', in Graber and Burri-Nenova, above n. 26, pp. 74-112.

68 A. Keen, The Cult of the Amateur: How Today's Internet Is Killing Our Culture (New York: Doubleday, 2007).

69 Netherlands Council for Culture, From ICT to E-Culture: Advisory Report on the Digitalisation of Culture and the Implications for Cultural Policy, submitted to the State Secretary for Education, Culture and Science, 2003 (English edn, 2004), p. 8. See also T. O’Regan and B. Goldsmith, 'Emerging Global Ecologies of Production', in D. Harries (ed.), The New Media Book (British Film Institute Publishing, 2004), pp. 92-105.

70 Such as the EC TV quotas for European content, as we have argued elsewhere. See M. Burri-Nenova, 'The New Audiovisual Media Services Directive: Television without Frontiers, Television without Cultural Diversity' (2007) 44 Common Market Law Review 1689. 
about the extremely narrow concentration of the trade and culture debate upon audiovisual media. ${ }^{71}$ The changed modalities of the digital space and the overall transformed environment call for a broader perspective when examining the pertinent issues of trade and culture and, as we argue in the following, for a new focal point of the cultural diversity debate. We suggest 'access' as the new focus of deliberations and construe it in the widest of contexts and as informed by the values of the freedom of speech and information. ${ }^{72}$ We argue that while the above-sketched effects of the new digital ecology may have positive repercussions and even promise a vital and diverse cultural environment sustainable without supplementary regulatory intervention, most of these effects would not unfold unless certain conditions of access, of practical, economic, societal and legal nature, are fulfilled.

\section{Access to infrastructure}

At the most basic level, increased diversity, distribution and access to the so-created information environment are strongly dependent upon access to infrastructure, hardware, software, and increasingly, access to media literacy. In a development discourse, this matrix is often used to identify the digital divide between the developed and the developing and least developed societies, although, as we signalled above, such gaps are the reality of industrialised societies too. We approach the matrix from a legal perspective here, however, and seek to unveil the legal constraints to this type of access. These legal limitations abound, especially as the digital networked environment matures, spreading 'at all levels of the information environment: the physical infrastructure layer - wires, cable, radio frequency spectrum - the logical infrastructure layer - software and the content layer, ${ }^{73}$ and making decisions previously peripheral to the cultural debate now move towards its centre. Thus, regulatory choices related to content cannot be analysed in isolation and any enquiry needs to incorporate and cautiously consider all choices made at all layers of the information and communication model.

71 Burri-Nenova, above n. 27.

72 J. M. Balkin, 'Media Access: A Question of Design' (2008) 76 George Washington Law Review 101

73 Y. Benkler, 'From Consumers to Users: Shifting the Deeper Structures of Regulation toward Sustainable Commons and User Access' (2000) 52 Federal Communications Law Journal 561. 
The infrastructural level falls within the domain of telecommunications law and this has traditionally been totally disassociated from media (content) regulation because of the inherent strict divide between content and networks that existed in the pre-convergence era. ${ }^{74}$ Such a divide is no longer apposite, especially as networks (in particular broadband) have become critical to accessing online media, or broadly speaking to entering the Information Society.

In this sense, the tremendous evolution of the telecommunications sector over the past two decades, its opening up to competition and undergoing substantial deregulation, are to be assessed as highly beneficial. ${ }^{75}$ The WTO rules have played a vital role in this process securing a level playing field and spreading the profits of deeper liberalisation among states. The GATS Annex on Telecommunications and the Reference Paper on Basic Telecommunications ${ }^{76}$ are particularly worthy of mention as instruments that go beyond the conventional services sector commitments and offer a progressive and suitable framework for advancing competition in telecommunications services. ${ }^{77}$ While there are a number of ways in which the Reference Paper could be improved to provide more clarity and stability of legitimate expectations, ${ }^{78}$ such improvements are highly unlikely to occur during the current Doha Round..$^{79}$ After MexicoTelecommunications, ${ }^{80}$ which exposed some of the drawbacks of the

74 Convergence is a complex process that can be briefly described as the coming together of media, telecommunications and information technologies markets and sectors. The process began in the mid-1980s and has been widely acknowledged as having deep regulatory implications in all policy circles. For an overview of stakeholders' positions, see M. Burri-Nenova, EC Electronic Communications and Competition Law (London: Cameron May, 2007), pp. 28-31.

75 Ibid., pp. 10-16.

76 Attached as an additional commitment (Article XIX GATS) to the Members' individual schedules of commitments.

77 For a detailed analysis, see M. Bronckers and P. Larouche, 'A Review of the WTO Regime for Telecommunications Services', in K. Alexander and M. Andenas (eds.), The World Trade Organization and Trade in Services (Leiden: Martinus Njihoff, 2008), pp. 319-379 and M. Burri-Nenova, 'The Law of the World Trade Organization and the Communications Law of the European Community: On a Path of Harmony or Discord?' (2007) 41 Journal of World Trade 833.

78 See e.g. D. Geradin and M. Kerf, 'Levelling the Playing Field: Is the WTO Adequately Equipped to Prevent Anti-Competitive Practices in Telecommunications?', in Geradin and Luff, above n. 13, pp. 144-157.

79 S. Peng, 'Trade in Telecommunications Services: Doha and Beyond' (2007) 41 Journal of World Trade 293.

80 WTO Panel Report, Mexico - Measures Affecting Telecommunications Services (Mexico Telecoms), WT/DS204/R, adopted 1 June 2004. 
Reference Paper, what also became especially palpable is the lack of competition rules within the WTO frame. ${ }^{81}$ The need for antitrust supervision is in fact stronger in the post-liberalisation period where sectoral regulation is gradually withdrawn and national competition agencies take over to ensure fair competition conditions, ${ }^{82}$ and it is unfortunate that any advance in the direction of incorporating competition rules within the WTO is far from becoming real at this stage. ${ }^{83}$

Yet, to reiterate with some optimism, the current telecommunications provisions at the international level do on the whole provide a fairly good basis for securing access to infrastructure. This is partly because their negotiation has been excluded from the politically laden 'trade versus culture' debates and has instead been driven by economic interests. Notwithstanding this economic rationale, it should be noted that the present regime also allows for the accommodation of national measures aimed at public interest objectives, since these can be subsumed under the universal service provision of the Reference Paper. ${ }^{84}$ The Reference Paper is formulated in a flexible manner and one may even argue that states can use this leeway to include content-related universal service obligations that secure not only access to infrastructure but also access to information. ${ }^{85}$ Indeed, there are numerous initiatives under way, both national and regional, aimed at securing 'broadband for all' ${ }^{86}$ as a first step along this avenue.

81 E. M. Fox, 'The WTO’s First Antitrust Case - Mexican Telecom: A Sleeping Victory for Trade and Competition' (2006) 9 Journal of International Economic Law 271, p. 290.

82 Burri-Nenova, above n. 74.

83 Although the synergies between trade and competition have been repeatedly acknowledged, there has been little progress since Singapore and the issue was dropped from the Doha agenda. See WTO, Doha Work Programme: Decision Adopted by the General Council on 1 August 2004, WT/L/579, 2 August 2004, para. (g). For a comprehensive analysis, see P. Marsden, A Competition Policy for the WTO (London: Cameron May, 2003).

84 With respect to universal service, the Reference Paper allows Members to define the type of universal service obligation they wish to maintain and states that such obligations will not be regarded as anti-competitive per se, provided that they are administered in a transparent, non-discriminatory and competitively neutral manner and are not more burdensome than necessary: Reference Paper, at section 3.

85 M. Burri-Nenova, 'The New Concept of Universal Service in a Digital Networked Communications Environment' (2007) 3 I/S: A Journal of Law and Policy for the Information Society 117.

86 See e.g. 'Empowering Users: The Key to the Development of the Information Society', speech by V. Reding, Member of the European Commission responsible for Information Society and Media at the BEUC Annual General Assembly, Brussels, 13 November 2008. 
Looking into the future and bearing in mind some developments at national level (mostly in the US and EC), what may be critical to ensuring access to infrastructure, broadly construed, will be all decisions that influence the interoperability of networks and code, ${ }^{87}$ the control of the network, ${ }^{88}$ as well as those pertinent to the principle of net neutrality. ${ }^{89}$ In respect of these, the lack of antitrust rules at the global level and the failure to recognise the principle of technological neutrality in the WTO realm ${ }^{90}$ are especially deplorable.

\section{Access to content}

1. The availability and organisation of information

As noted above, under the conditions of the digital networked environment, content abounds. Yet, this does not automatically mean that information is readily accessible and if it is, it may not be easy to find. The fact that any type of data can be expressed in digital format has changed the rules for organising information. ${ }^{91}$ So whereas the Dewey decimal classification used to be used for organising libraries and alphabetical order was used for name registers and genre categories in CD shops, the digital environment enables an encompassing, global, extremely miscellaneous and dynamic information archive that can be searched through a single entry point according to virtually unlimited criteria. This has been made technologically possible through the availability and continuous improvement of search engines that serve as linchpins of the Internet. ${ }^{92}$ As the importance of these technological facilitators, which are essentially under private property and control, grows, it will become necessary

87 U. Gasser and J. G. Palfrey. 'Breaking Down Digital Barriers: When and How ICT Interoprability Drives Innovation' (2007) Berkman Center Research Publication No. 08.

88 J. G. Palfrey, Jr. and R. Rogoyski, 'The Move to the Middle: The Enduring Threat of "Harmful" Speech to the End-to-End Principle' (2006) 21 Washington University Journal of Law and Policy 31.

89 The principle of net(work) neutrality holds that the network should be neutral to the content being passed and that intermediaries should pass all packets, while the intelligence is located at the edges of the network where necessary See S. P. Crawford, 'Network Rules' (2007) 70 Law and Contemporary Problems 51; T. Wu, 'Network Neutrality, Broadband Discrimination' (2003) 2 Journal on Telecommunications and High Technology Law 141.

90 P. Larouche, 'Dealing with Convergence at the International Level', in Geradin and Luff, above n. 13, pp. 390-422.

91 Weinberger, above n. 64.

92 J. Grimmelmann, 'The Structure of Search Engine Law' (2007) New York Law School Research Paper Series 23, p. 2. See also J. Battelle, The Search (Portfolio, 2005). 
to ensure that precision, universal access and non-discrimination are guaranteed..$^{93}$ Possible impediments to gaining access to content due to either filtering by the incumbent company or by the state (through commercial intermediaries ${ }^{94}$ ) have also an essential human rights dimension in that they may infringe the freedoms of expression and information, association or privacy. ${ }^{95}$ While the scope of this chapter does not allow a full analysis, it is apparent that there is a host of new issues arising in this context that the international legal framework is not yet prepared to reflect appropriately. ${ }^{96}$

\section{Intellectual property rights}

In contrast, intellectual property rights (IPR) protection has long been secured at the international level and the contemporary IPR architecture ${ }^{97}$ has evolved over time and elaborated a broad palette of sophisticated and flexible intellectual property (IP) tools 'to protect both traditional and new forms of symbolic value produced in particular places as they circulate in global commodity markets. ${ }^{98}$ When talking about trade and

93 Vaidhyanathan, for instance, questions the role of Google as ubiquitous search engine and asks whether public libraries may be more appropriate to administer knowledge. See S. Vaidhyanathan, 'The Googlization of Everything and the Future of Copyright' (2007) 40 UC Davis Law Review 1207, p. 1220. For a more optimistic vision, see L. A. Kurtz, 'Copyright and the Human Condition' (2007) 40 UC Davis Law Review 1233, pp. 1250-1251.

94 J. Rosen, 'Google’s Gatekeepers', New York Times, 30 November 2008.

95 Internet filtering has been practised by many states with different degrees of intervention, China being the most prominent example. See R. J. Deibert et al., Access Denied: The Practice and Policy of Global Internet Filtering (MIT Press, 2007).

96 There have been some private initiatives to remedy the situation, at least partially. For instance, the Center for Democracy and Technology and Business for Social Responsibility, together with leading human rights groups, academic institutions and ICT companies, including Google, Vodafone, France Telecom, Microsoft and Yahoo! have launched a project to protect and advance individuals' rights to free expression and privacy on the Internet through the creation of a set of principles and supporting mechanisms for ICT companies. See www.globalnetworkinitiative.org/.

97 Under IPR as a general category, one understands the rights granted to creators and inventors to control the use made of their productions. They are traditionally divided into two main branches: (i) 'copyright and related (or neighbouring) rights' for literary and artistic works and (ii) 'industrial property', which encompasses trademarks, patents, industrial designs, geographical indications and the layout designs of integrated circuits. In the following, we discuss primarily the first category.

98 R. J. Coombe, S. Schnoor and M. Ahmed, 'Bearing Cultural Distinction: Informational Capitalism and New Expectations for Intellectual Property' (2007) 40 UC Davis Law Review 891, p. 916. 
culture, IPR are particularly vital for (at least) two reasons: the first has to do with the foremost rationale for IPR protection, which is to foster creativity; ${ }^{99}$ this is also essentially the most important prerequisite for a flourishing and diverse cultural environment. The second reason has to do with the way IPR protection is granted, whereby authors receive a temporary monopoly over their creations and thus exclude the rest of the public from having access to the protected works. ${ }^{100}$ Within both of these rationales, which are essentially interrelated, a series of critiques from the perspective of protecting and promoting cultural diversity can be formulated.

First, the IPR system is far from perfect and some of its deficiencies relate to the inherent centrality of authorship, originality and mercantilism in the 'Western' IP model, which leaves numerous non-Western, collaborative or folkloric modes of production outside the scope of IP protection. ${ }^{101}$ It is furthermore not certain whether the existent IP model appropriately reflects - especially under the conditions of the digital ecology, which have magnified the value of copyright law ${ }^{102}$ and expanded its reach $^{103}$ - the precarious balance between the private interests of authors and the public interest in enjoying broad access to their productions, ${ }^{104}$

99 As the US Constitution (at Article I, Section 8, para. 8) beautifully puts it: ' $\mathrm{t}$ ] o promote the Progress of Science and useful Arts, by securing for limited Times to Authors and Inventors the exclusive Right to their respective Writings and Discoveries'.

100 It should also be mentioned here that while this monopoly was initially vested in the creators, presently 'these rights are routinely assigned away to the distributor of the work in order to gain access to the channels of distribution and their audience'. See R. Ku, 'Promoting Diverse Cultural Expression: Lessons from the US Copyright Wars' (2007) 2 Asian Journal of WTO and International Health Law and Policy 369, p. 377, referring also to N. W. Netanel, 'Market Hierarchy and Copyright in Our System of Free Expression' (2000) 53 Vanderbilt Law Review 1879, p. 1889.

101 See the contributions to C. B. Graber and M. Burri-Nenova (eds.), Intellectual Property and Traditional Cultural Expressions in a Digital Environment (Cheltenham: Edward Elgar, 2008), in particular these of F. Macmillan, W. B. Wendland, C. B. Graber and M. Burri-Nenova.

102 J. E. Cohen, 'Pervasively Distributed Copyright Enforcement' (2006) 95 Georgetown Law Journal 1.

103 L. Lessig, '(Re)creativity: How Creativity Lives', in H. Porsdam (ed.), Copyright and Other Fairy Tales: Hans Christian Andersen and the Commodification of Creativity (Cheltenham: Edward Elgar, 2006), pp. 15-22, p. 19.

104 See e.g. Committee on Economic, Social and Cultural Rights, General Comment No. 17: The Right of Everyone to Benefit from the Protection of the Moral and Material Interests Resulting from Any Scientific, Literary or Artistic Production of Which He Is the Author (Article 15(1)(c)), UN Doc. E/C.12/2005, 21 November 2005, para. 35. 
and whether this balance offers the best incentives to promote creativity. The content industries are quite sure of copyright's virtues and have convinced most governments that strong and enforceable IPRs are the sine qua non for a vibrant culture. Through race-to-the-top strategies, this strong protection has been emancipated to the international level in the framework of the Agreement on Trade Related Aspects of Intellectual Property Rights (TRIPS Agreement) and in the even further-reaching free trade agreements. ${ }^{105}$

Yet, while IP protection certainly fulfils essential economic functions in production and distribution of cultural materials, ${ }^{106}$ evidence of a direct correlation between IPR and creativity is equivocal and IP protection may even trigger systemic harm. ${ }^{107}$ Furthermore, some copyright scholars observing the process of creativity more closely argue that it is the 'creative play' that is of primary importance for artistic and intellectual innovation. ${ }^{108}$ The existing copyright models do not reflect such arguments. Especially under the conditions of the digital networked environment, these models are often too rigid to allow full realisation of the possibilities of the digital mode of content production and distribution, or render them illegal, possibly chilling a considerable amount ${ }^{109}$ of creative activities and creative potential. ${ }^{110}$ These deficiencies have been exposed by the emergence of new hybrid models for the protection of authors' rights, such as the Creative Commons (cc) licence, ${ }^{111}$ which short of a

105 N. W. Netanel, 'Why Has Copyright Expanded? Analysis and Critique', in F. Macmillan (ed.), New Directions in Copyright Law, vol. 6 (Cheltenham: Edward Elgar, 2007), pp. 3-34.

106 W. M. Landes and R. A. Posner, The Economic Structure of Intellectual Property Law (Cambridge, MA: Belknap Press of Harvard University, 2003), pp. 11-123.

107 J. E. Cohen, 'Creativity and Culture in Copyright Theory' (2007) 40 UC Davis Law Review 1151,pp. 1193-1194. In Grokster, the US Supreme Court did recognise the possible harm, noting that, ' $\mathrm{t}$ ] he more artistic protection is favored, the more technological innovation may be discouraged': see US Supreme Court, Metro-Goldwyn-Mayer Studios, Inc. v. Grokster, Ltd., 125 S. Ct. 2764 (2005), referring to Sony Corp. of America v. Universal City Studios, Inc., 464 U. S. 417 (1984), at 442.

108 See Cohen, above n. 107, and J. E. Cohen, 'The Place of the User in Copyright Law' (2005) 74 Fordham Law Review 347.

109 Vaidhyanathan notes in this regard: 'Copyright in recent years has certainly become too strong for its own good. It protects more content and outlaws more acts than ever before. It stifles creativity and hampers the discovery and sharing of culture and knowledge': see Vaidhyanathan, above n. 93, p. 1210. See also S. Vaidhyanathan, Copyrights and Copywrongs: The Rise of Intellectual Property and How It Threatens Creativity (New York: New York University Press, 2003).

110 Burri-Nenova, above n. 67.111 See http://creativecommons.org/. 
comprehensive copyright reform, allow content to be managed and spread under a 'some rights reserved' mode. ${ }^{112}$

Such developments have also been partly a reaction to the particularly troublesome mechanisms of Digital Rights Management systems (DRM) and other technological protection measures, which under the guise of protecting digital content from uncontrolled distribution and unlawful use, have had pernicious effects, thereby eroding some fundamental rights of consumers ${ }^{113}$ and restricting usages traditionally allowed under copyright. ${ }^{114}$

To wrap up the above argument, the initial raison d'être for copyright ${ }^{115}$ may need to be restated in the newly formed environment, and this is not simply a matter of yielding to the media industries' lobbying, but of weighing anew private interests against public values. ${ }^{116}$ Ensuring sustainable access to cultural goods and sustainable production of culturally diverse content ${ }^{117}$ would thus not mean that everything is accessible in the romantic sense of the public domain ${ }^{118}$ but would involve a complex balance between openness and discretion. ${ }^{119}$

112 Under a cc-licence, the creator/licensor may shape her or his package of rights applying different conditions to the licensed work (attribution; non-commercial; no derivatives; or share alike). Such models have also proven to feed back positively into the usercreated content creation and dissemination, thereby enhancing content diversity (see OECD, above n. 64, p. 14).

113 C.B. Graber, 'Copyright and Access - a Human Rights Perspective', in C.B. Graber et al. (eds), Digital Rights Management: The End of Collecting Societies? (Bern: Staempfli, 2005), pp. 71-110.

114 N. Lucchi, 'Countering the Unfair Play of DRM Technologies' (2007) 16:1 Texas Intellectual Property Law Journal 91.

115 R. Deazley, Rethinking Copyright: History, Theory, Language (Cheltenham: Edward Elgar, 2008).

116 See L. Lessig, Free Culture (New York: Penguin, 2004).

117 R. J. Coombe, 'Protecting Cultural Industries to Promote Cultural Diversity: Dilemma for International Policy-Making Posed by the Recognition of Traditional Knowledge', in K. E. Maskus and J. H. Reichman (eds.), International Public Goods and Transfer of Technology under a Globalized Property Regime (Cambridge University Press, 2005), pp. 559-614, p. 613.

118 See A. Chander and M. Sunder, 'The Romance of the Public Domain' (2004) 92 California Law Review 1331.

119 See R. J. Coombe, 'Fear, Hope, and Longing for the Future of Authorship and a Revitalized Public Domain in Global Regimes of Intellectual Property' (2003) 52 DePaul Law Review 1171. Various proposals have already been advanced. With regard to liability rules, see J. H. Reichman and T. Lewis, 'Using Liability Rules to Stimulate Local Innovation in Developing Countries: Application to Traditional Knowledge', in Maskus and Reichman, above n. 117, pp. 337-366. See also the work of NCCR Individual Project No. 9, as highlighted in this volume. 
The World Intellectual Property Organization (WIPO) itself has admitted that certain amendments to the existing IP architecture and a search for new forms are necessary because of the need for: (i) the preservation and safeguarding of intangible cultural heritage; (ii) the promotion of cultural diversity; and (iii) the promotion of creativity and innovation, including tradition-based forms. ${ }^{120}$ The WIPO Development Agenda, adopted by the WIPO General Assembly in September $2007^{121}$ equally rejects a purely IP-centric view. 'It posits that strong intellectual property protection does not consistently promote creative activity, facilitate technology transfer, or accelerate development' and 'places the benefits of a rich and accessible public domain, national flexibilities in implementing IP treaty norms, access to knowledge, UN development goals, curbing of IP-related anti-competitive practices, and the need to balance the costs and benefits of intellectual property protection firmly within WIPO's central mission.' ${ }^{122}$ It remains to be seen how these initiatives will be implemented and linked to the TRIPS framework and what their overall effect upon the international trade system will be. ${ }^{123}$

\section{F. Conclusions: from fragmentation to coherence?}

The area of trade and culture reveals extreme fragmentation and 'no homogenous, hierarchical meta-system is realistically available to do away with such problems of [conflicting rules and overlapping legal regimes].' ${ }^{124}$ In addition, and typical of 'trade and culture' issues, it is not only the regulatory framework that is profoundly fragmented but also the policy discussions.

Such fragmentation and the increasing politically driven disconnect between the issues of trade and culture complicate and partly obstruct

120 WIPO Intergovernmental Committee on Intellectual Property and Genetic Resources, Traditional Knowledge and Folklore, Consolidated Analysis of the Legal Protection of Traditional Cultural Expressions, WIPO/GRTKF/IC/5/3, 2 May 2003, Annex, para. 8.

121 WIPO Doc. A/43/16, at Annex A.

122 N. W. Netanel, 'The WIPO Development Agenda and its Development Policy Context', in N. W. Netanel, The Development Agenda: Global Intellectual Property and Developing Countries (Oxford University Press, 2009), pp. 1-32, p. 2.

123 In the same vein, see J. de Beer (ed.), Implementing the World Intellectual Property Organization's Development Agenda (Waterloo, ON: Wilfrid Laurier University Press, 2009).

124 United Nations, Fragmentation of International Law: Difficulties Arising from the Diversification and Expansion of International Law, Report of the Work of the Study Group of the International Law Commission, finalised by Martti Koskenniemi, A/CN.4/L.682, 13 July 2006, para. 493. 
the process of identifying coherent solutions. While under 'coherent' we certainly do not mean uniform 'one-size-fits-all' regulatory solutions, we believe that there are a number of ways in which the existing framework can be improved to make it both more trade enhancing and more conducive to cultural considerations.

The modified market mechanisms for content and the changed conditions for creativity, as well as for production, distribution and consumption of cultural content in the digital networked environment, can be viewed as an opportunity in this regard, allowing (if not indeed demanding) a re-evaluation. First it is necessary to acknowledge that we are now faced with a situation that is 'significantly different from the audiovisual sector of the Uruguay Round when negotiations focused primarily on film production, film distribution, and terrestrial broadcasting of audiovisual goods and services ${ }^{125}$ and that is even different from the conditions prevailing at the outset of the Doha Round in 2001, when the Internet was in its infancy and the implications of this network of networks were largely unknown.

We do not, however, suggest that cultural policy measures should be abandoned and that the free flow of goods and services alone will cater for a diversity of expressions in the newly formed environment. Yet the benefits of the existing trade restrictions may very well prove not to outweigh their costs and indeed may be detrimental to the goal of cultural diversity. ${ }^{126}$ One may even argue that it is within the mandate of the UNESCO Convention, the scope of which certainly goes beyond the plain reservation of 'shelf-space for domestic productions in television programs and cinemas, ${ }^{127}$ to encourage the ratifying parties to dismantle some trade barriers.

Whereas the emergence of a global digital environment and some of its effects have increasingly been acknowledged, it has yet to become an essential issue of policy-making or to be sufficiently integrated into any of the 'old' rule-making domains, notably trade and culture. We argue that access, taken in its broadest sense, offers the appropriate focus in the cultural diversity deliberations. This would most probably call for actions outside the extremely constrained domain of audiovisual services

125 WTO, Communication from the United States: Audiovisual and Related Services, S/CSS/W/21, 18 December 2000, para. 2.

126 J. P. Singh, 'Culture or Commerce? A Comparative Assessment of International Interactions and Developing Countries at UNESCO, WTO, and Beyond' (2007) 8 International Studies Perspectives 36, p. 42.

127 Hahn, above n. 49, p. 533. 
and require adjustments in other regulatory fields, most notably that of intellectual property protection.

In the concrete terms of a WTO reform and in view of the changing media environment, an important avenue for improving the WTO framework could be the redesign of the existing services classification. A clearer, better-structured and up-to-date classification, especially with regard to the sectors pertinent to culture and the rapidly changing audiovisual and telecommunications areas, can be put high on the list of desiderata. ${ }^{128}$ Such an improved system could, most importantly in the present context, allow finer-tuned scheduling rather than the existing 'all-or-nothing' approach. It could also facilitate deeper market access commitments not only in the services sectors (such as computer and telecommunications services), where this may reasonably be expected. Achieving a level of legal certainty with regard to the classification may also contribute to resolving the dilemma of classifying digitally transferred products and services, as outlined above in the context of digital games.

As a more comprehensive improvement plan, there is a good deal that can be achieved by taking up the unfinished business of the Uruguay Round. The 'framework of GATS rules and disciplines is still very much under construction' ${ }^{\prime 29}$ and, as well as the progressive liberalisation through more and deeper commitments (Article XIX GATS), the GATS structure needs to be completed with rules on: (i) emergency safeguard measures (Article X:1); (ii) subsidies (Article XV:1); (iii) government procurement (Article XIII:2); and (iv) domestic regulation (Article VI:4). ${ }^{130}$ While all of these projects ${ }^{131}$ would make the rules of the GATS finergrained, thereby also allowing better-tuned commitments, ${ }^{132}$ new rules

128 The need for careful scheduling has been stressed by the US - Gambling rulings. See WTO Panel Report, Panel Report, United States - Measures Affecting the Cross-Border Supply of Gambling and Betting Services (US - Gambling), WT/DS285/R, 10 November 2004, as modified by the Appellate Body Report, WT/DS285/AB/R and WTO Appellate Body Report, United States - Measures Affecting the Cross-Border Supply of Gambling and Betting Services (US - Gambling), WT/DS285/AB/R, adopted 20 April 2005.

129 Pierre Sauvé, 'Completing the GATS Framework: Addressing Uruguay Round Leftovers' (2002) 3 Aussenwirtschaft 301, p. 302.

130 Ibid., pp. 302-303.

131 For an analysis of these undertakings, see Sauvé, ibid., as well as P. Sauvé, 'Been There, Not Yet Done That: Lessons and Challenges in Services Trade', in M. Panizzon, N. Pohl and P. Sauvé (eds.), GATS and the Regulation of International Trade in Services (Cambridge University Press, 2008), pp. 599-631.

132 We noted above that GATS allows substantially more flexibility than the GATT. It should however be borne in mind that if Members do make unlimited commitments under GATS, they may in fact be more restricted than under GATT since within the fairly new 
on subsidies ${ }^{133}$ are to be viewed as particularly appropriate in the context of trade and culture. The audiovisual sector is one of the traditionally subsidised ones ${ }^{134}$ and 'often subsidies are the most efficient instrument for pursuing noneconomic objectives, ${ }^{135}$ possibly also for the protection and promotion of local or national culture. Furthermore, the US has noted in this respect that, 'Members may also want to consider developing an understanding on subsidies that will respect each nation's need to foster its cultural identity by creating an environment to nurture local culture, ${ }^{136}$ so there may be some tolerance already.

Finally, one should mention the possibility of inserting competition rules within the WTO legal framework ${ }^{137}$ that would deal with market distortions by private undertakings. ${ }^{138}$ Such rules could be particularly helpful considering that digital media are by default global in their distribution and new media providers operate regardless of borders. This is, however, perhaps the least feasible of avenues, bearing in mind the little progress made since Singapore ${ }^{139}$ and that the issue was dropped from the Doha agenda. ${ }^{140}$

construct of the agreement on services no rules on subsidies, safeguards or an equivalent to GATT Article IV for screen quotas exist.

133 Although the current GATS framework contains no specific rules on subsidies, subsidies are not excluded from GATS' scope of application. As 'measures by Members affecting trade in services' within the meaning of Article I:1, subsidies are fully covered by the provisions of the GATS. There are a number of GATS provisions that restrict governments' ability to provide services subsidies or to offer a remedy to those Members harmed by their negative effects. See P. Poretti, 'Waiting for Godot: Subsidy Disciplines in Services Trade', in Panizzon et al., above n. 131, pp. 466-488.

134 Sauvé, above n. 129, p. 325.

135 B. Hoekman, 'Toward a More Balanced and Comprehensive Services Agreement' in J. J. Schott (ed.), The WTO after Seattle (Washington, DC: Institute for International Economics, 2000), pp. 119-135, p. 129.

136 WTO, Communication from the United States, above n. 125, para. 10(iii). The US has already accepted some leeway for subsidies in its FTAs with Singapore and Australia.

137 Marsden, above n. 83; M. E. Janow, 'Trade and Competition Policy', in P. F. J. Macrory, A. E. Appleton and M. G. Plummer (eds.), The World Trade Organization: Legal, Economic and Political Analysis, vol. 3 (Berlin: Springer, 2005), pp. 487-510.

138 Germann, above n. 62, p. 111; Graber, above n. 3, pp. 317-328, 343.

139 WTO, Singapore Ministerial Declaration, WT/MIN(96)/DEC/W, 13 December 1996. The Singapore Declaration (para. 20) mandated the establishment of 'a working group to study issues raised by Members relating to the interaction between trade and competition policy, including anti-competitive practices, in order to identify any areas that may merit further consideration in the WTO framework'

140 WTO, Doha Work Programme: Decision Adopted by the General Council on 1 August 2004, WT/L/579, 2 August 2004, para. (g). 
To conclude, one needs to acknowledge that there is a growing understanding of the potency of digital technologies as tools and a corresponding flurry of declaratory messages stating that digital technologies could and should be operationalised ${ }^{141}$ for the pursuit of diverse public interest objectives, including cultural diversity. Yet, a concrete approach encompassing all pertinent regulatory fields is still lacking. It is perhaps reasonable to start such an exercise at the national level, where a deeper and finer-grained understanding of the effects of the digital networked environment upon creativity, cultural content production, dissemination and consumption can be gained. This knowledge might prompt the formulation of new priorities, ${ }^{142}$ which, without compromising cultural diversity as a valid regulatory objective, may lead to a readjustment of the tools of cultural policy regulation at diverse levels of governance. As we have argued, this may mean that barriers, both of legal and of practical nature, relating to the movement of content and to access to content, need to be lifted, while well-targeted subsidies systems, for instance for productions in local languages, for infrastructural support or efforts at bridging the digital divide, are put in place. The WTO law has the potential to accommodate such changes if the political will is there.

\section{Bibliography}

Anderson, Chris, The Long Tail: Why the Future of Business is Selling Less of More (New York: Hyperion, 2006).

Balkin, Jack M., 'Media Access: A Question of Design' (2008) 76 George Washington Law Review 933-951.

Battelle, John, The Search (New York: Portfolio, 2005).

Benkler, Yochai, 'From Consumers to Users: Shifting the Deeper Structures of Regulation toward Sustainable Commons and User Access' (2000) 52 Federal Communications Law Journal 561-580.

Benkler, Yochai, The Wealth of Networks: How Social Production Transforms Markets and Freedom (New Haven, CT: Yale University Press, 2006).

Bernier, Ivan, 'A UNESCO International Convention on Cultural Diversity', in C. B. Graber, M. Girsberger and M. Nenova (eds.), Free Trade versus Cultural Diversity: WTO Negotiations in the Field of Audiovisual Services (Zurich: Schulthess, 2004), pp. 65-76.

141 For an overview, see T. McGonagle, 'The Promotion of Cultural Diversity via New Media Technologies: An Introduction to the Challenges of Operationalisation' (2008) 6 IRIS: Legal Observations of the European Audiovisual Observatory 1.

142 With specific regard to audiovisual media, see Burri-Nenova, above n. 57. 
Bronckers, M. C. E. J. and Larouche, Pierre, 'A Review of the WTO Regime for Telecommunications Services', in K. Alexander and M. Andenas (eds.), The World Trade Organization and Trade in Services (Leiden: Martinus Njihoff, 2008), pp. 319-379.

Bruner, Christopher M., 'Culture, Sovereignty, and Hollywood: UNESCO and the Future of Trade in Cultural Products' (2008) 40 International Law and Politics 351-436.

Brynjolfsson, Erik, Hu, Yu Jeffrey and Smith, Michael D., 'From Niches to Riches: The Anatomy of the Long Tail' (2006) 47 Sloan Management Review, pp. 67-71.

Brynjolfsson, Erik, Hu, Yu Jeffrey and Simester, Duncan, 'Goodbye Pareto Principle, Hello Long Tail: The Effect of Search Costs on the Concentration of Product Sales' (2007) MIT Center for Digital Business Working Paper.

Burri-Nenova, Mira, EC Electronic Communications and Competition Law (London: Cameron May, 2007).

Burri-Nenova, Mira, 'The New Concept of Universal Service in a Digital Networked Communications Environment' (2007) 3 I/S: A Journal of Law and Policy for the Information Society 117-146.

Burri-Nenova, Mira, 'The New Audiovisual Media Services Directive: Television without Frontiers, Television without Cultural Diversity' (2007) 44 Common Market Law Review 1689-1725.

Burri-Nenova, Mira, 'The Law of the World Trade Organization and the Communications Law of the European Community: On a Path of Harmony or Discord?' (2007) 41 Journal of World Trade 833-878.

Burri-Nenova, Mira, 'The Changing Environment of Audiovisual Media: New Technologies, New Patterns of Consumer/Business Behaviour and Their Implications for Audiovisual Media Regulation' (2007) 12 medialex 171-177.

Burri-Nenova, Mira, 'Trade and Culture: Making the WTO Legal Framework Conducive to Cultural Considerations' (2008) 5 Manchester Journal of International Economic Law 3-39.

Burri-Nenova, Mira, 'The Long Tail of the Rainbow Serpent: New Technologies and the Protection and Promotion of Traditional Cultural Expressions', in C. B. Graber and M. Burri-Nenova (eds.), Intellectual Property and Traditional Cultural Expressions in a Digital Environment (Cheltenham: Edward Elgar, 2008), pp. 205-236.

Burri-Nenova, Mira, 'Trade versus Culture in the Digital Environment: An Old Conflict in Need of a New Definition' (2009) 12 Journal of International Economic Law 17-62.

Burri-Nenova, Mira, 'User Created Content in Virtual Worlds and Cultural Diversity', in C. B. Graber and M. Burri-Nenova (eds.), Governance of Digital Game Environments and Cultural Diversity (Cheltenham: Edward Elgar, 2010), pp. $74-112$. 
Burri-Nenova, Mira, 'Trade and Culture in International Law: Paths to (Re)conciliation' (2010) 44 Journal of World Trade 49-80.

Cahn, Sandrine and Schimmel, Daniel, 'The Cultural Exception: Does It Exist in GATT and GATS Frameworks? How Does It Affect or Is It Affected by the Agreement on TRIPS?' (1997) 15 Cardozo Arts and Entertainment Law Journal 281-314.

Chander, Anupam and Sunder, Madhavi, 'The Romance of the Public Domain' (2004) 92 California Law Review 1331-1374.

Chang, Seung Wha, 'WTO for Trade and Development Post-Doha' (2007) 10 Journal of International Economic Law 553-570.

Choi, Won M., 'Screen Quota and Cultural Diversity: Debates in Korea-US FTA Talks and Convention on Cultural Diversity' (2007) 2 Asian Journal of WTO and International Health Policy 267-286.

Cohen, Julie E., 'The Place of the User in Copyright Law' (2005) 74 Fordham Law Review 347-374.

Cohen, Julie E., 'Pervasively Distributed Copyright Enforcement' (2006) 95 Georgetown Law Journal 1-48.

Cohen, Julie E., 'Creativity and Culture in Copyright Theory' (2007) 40 UC Davis Law Review 1151-1206.

Coombe, Rosemary J., 'Fear, Hope, and Longing for the Future of Authorship and a Revitalized Public Domain in Global Regimes of Intellectual Property' (2003) 52 DePaul Law Review 1171-1192.

Coombe, Rosemary J., 'Protecting Cultural Industries to Promote Cultural Diversity: Dilemma for International Policy-Making Posed by the Recognition of Traditional Knowledge', in K. E. Maskus and J. H. Reichman (eds.), International Public Goods and Transfer of Technology under a Globalized Property Regime (Cambridge University Press, 2005), pp. 559-614

Coombe, Rosemary J., Schnoor, Steven and Ahmed, Mohsen, 'Bearing Cultural Distinction: Informational Capitalism and New Expectations for Intellectual Property' (2007) 40 UC Davis Law Review 891-918.

Cowen, Tyler, In Praise of Commercial Culture (Cambridge, MA: Harvard University Press, 1998).

Cowen, Tyler, Creative Destruction: How Globalization Is Changing the World's Cultures (Princeton, NJ: Princeton University Press, 2002).

Craufurd Smith, Rachael, 'The UNESCO Convention on the Protection and Promotion of Cultural Expressions: Building a New World Information and Communication Order?' (2007) 1 International Journal of Communication 24-55.

Crawford, Susan P., 'Network Rules' (2007) 70 Law and Contemporary Problems 51-90.

Deazley, Ronan, Rethinking Copyright: History, Theory, Language (Cheltenham: Edward Elgar, 2008). 
de Beer, Jeremy (ed.), Implementing the World Intellectual Property Organization's Development Agenda (Waterloo, ON: Wilfrid Laurier University Press, 2009).

Deibert, Ronald J. et al., Access Denied: The Practice and Policy of Global Internet Filtering (Cambridge, MA: MIT Press, 2007).

Fox, Eleanor M., 'The WTO's First Antitrust Case - Mexican Telecom: A Sleeping Victory for Trade and Competition' (2006) 9 Journal of International Economic Law 271-292.

Gabler, Neal, An Empire of Their Own: How the Jews Invented Hollywood (New York: Anchor, 1988).

Galt, Frederick S., 'The Life, Death, and Rebirth of the "Cultural Exception" in the Multilateral Trading System: An Evolutionary Analysis of Cultural Protection and Intervention in the Face of American Pop Culture's Hegemony' (2004) 3 Washington University Global Studies Law Review 909-936.

Gasser, Urs and Palfrey, John G., 'Breaking Down Digital Barriers: When and How ICT Interoperability Drives Innovation' (2007) Berkman Center Research Publication No. 08.

Geradin, Damien and Kerf, Michel, 'Levelling the Playing Field: Is the WTO Adequately Equipped to Prevent Anti-Competitive Practices in Telecommunications?', in D. Geradin and D. Luff (eds.), The WTO and Global Convergence in Telecommunications and Audiovisual Services (Cambridge University Press, 2004), pp. 144-157.

Germann, Christophe, 'Culture in Times of Cholera: A Vision for a New Legal Framework Promoting Cultural Diversity' (2005) 6 ERA-Forum 109-130.

Giddens, Anthony, Runaway World: How Globalisation Is Reshaping Our Lives (Oxford: Routledge, 2002).

Goodman, Ellen P., 'Media Policy Out of the Box: Content Abundance, Attention Scarcity, and the Failures of Digital Markets' (2004) 19 Berkeley Technology Law Journal 1389-1472.

Graber, Christoph Beat, Handel und Kultur im Audiovisionsrecht der WTO (Bern: Staempfli, 2003).

Graber, Christoph Beat, 'Audiovisual Media and the Law of the WTO', in C. B. Graber, M. Girsberger and M. Nenova (eds.), Free Trade versus Cultural Diversity: WTO Negotiations in the Field of Audiovisual Services (Zurich: Schulthess, 2004), pp. 47-56.

Graber, Christoph Beat, 'Audio-visual Policy: The Stumbling Block of Trade Liberalisation', in D. Geradin and D. Luff (eds.), The WTO and Global Convergence in Telecommunications and Audiovisual Services (Cambridge University Press, 2004), pp. 165-214.

Graber, Christoph Beat, 'Copyright and Access - a Human Rights Perspective', in C. B. Graber et al. (eds.), Digital Rights Management: The End of Collecting Societies? (Bern: Staempfli, 2005), pp. 71-110. 
Graber, Christoph Beat, 'The New UNESCO Convention on Cultural Diversity: A Counterbalance to the WTO?' (2006) 9 Journal of International Economic Law 553-574.

Graber, Christoph Beat, 'Using Human Rights to Tackle Fragmentation in the Field of Traditional Cultural Expressions: An Institutional Approach', in C. B. Graber and M. Burri-Nenova (eds.), Intellectual Property and Traditional Cultural Expressions in a Digital Environment (Cheltenham: Edward Elgar, 2008), pp. 96-120.

Graber, Christoph Beat, 'Substantive Rights and Obligations under the UNESCO Convention on Cultural Diversity', in H. Schneider and P. van den Bossche (eds.), Protection of Cultural Diversity from an International and European Perspective (Mortsel: Intersentia, 2008), pp. 141-162.

Graber, Christoph Beat, 'State Aid for Digital Games and Cultural Diversity: A Critical Reflection in the Light of EU and WTO Law', in C. B. Graber and M. Burri-Nenova (eds.), Governance of Digital Game Environments and Cultural Diversity (Cheltenham: Edward Elgar, 2010), pp. 170-201.

Grimmelmann, James, 'The Structure of Search Engine Law' (2007) New York Law School Research Paper Series 23.

Hahn, Michael, 'A Clash of Cultures? The UNESCO Diversity Convention and International Trade Law' (2006) 9 Journal of International Economic Law $515-552$.

Hoekman, Bernard, 'Toward a More Balanced and Comprehensive Services Agreement' in J. J. Schott (ed.), The WTO after Seattle (New York: Institute for International Economics, 2000), pp. 119-135.

Hoekman, Bernard, 'More Favorable Treatment of Developing Countries: Ways Forward', in R. Newfarmer (ed.), Trade, Doha, and Development: Window into the Issues (Washington, DC: World Bank, 2006), pp. 213-221.

Janow, Merit E., 'Trade and Competition Policy', in P. F. J. Macrory, A. E. Appleton and M. G. Plummer (eds.), The World Trade Organization: Legal, Economic and Political Analysis, vol. 3 (Berlin: Springer, 2005), pp. 487-510.

Keen, Andrew, The Cult of the Amateur: How Today's Internet Is Killing Our Culture (New York: Doubleday, 2007).

$\mathrm{Ku}$, Raymond S. R., 'Promoting Diverse Cultural Expression: Lessons from the US Copyright Wars' (2007) 2 Asian Journal of WTO and International Health Law and Policy 369-398.

Kurtz, Leslie A., 'Copyright and the Human Condition' (2007) 40 UC Davis Law Review 1233-1252.

Landes, William M. and Posner, Richard A., The Economic Structure of Intellectual Property Law (Cambridge, MA: Belknap Press of Harvard University, 2003), pp. 11-123. 
Larouche, Pierre, 'Dealing with Convergence at the International Level', in D. Geradin and D. Luff (eds.), The WTO and Global Convergence in Telecommunications and Audiovisual Services (Cambridge University Press, 2004), pp. 390-422.

Lessig, Lawrence, Free Culture (New York: Penguin, 2004).

Lessig, Lawrence, '(Re)creativity: How Creativity Lives', in H. Porsdam (ed.), Copyright and Other Fairy Tales: Hans Christian Andersen and the Commodification of Creativity (Cheltenham: Edward Elgar, 2006), pp. 15-22.

Lucchi, Nicola, 'Countering the Unfair Play of DRM Technologies' (2007) 16 Texas Intellectual Property Law Journal 91-124.

Macmillan, Fiona, 'Human Rights, Cultural Property and Intellectual Property: Three Concepts in Search of a Relationship', in C. B. Graber and M. BurriNenova (eds.), Intellectual Property and Traditional Cultural Expressions in a Digital Environment (Cheltenham: Edward Elgar, 2008), pp. 73-95.

Marsden Chris et al., Assessing Indirect Impacts of the EC Proposals for Video Regulation (RAND Europe, 2006).

Marsden, Philip, A Competition Policy for the WTO (London: Cameron May, 2003).

McGonagle, Tarlach, 'The Promotion of Cultural Diversity via New Media Technologies: An Introduction to the Challenges of Operationalisation' (2008) 6 IRIS: Legal Observations of the European Audiovisual Observatory 7.

Naughton, John, 'Our Changing Media Ecosystem', in E. Richards et al. (eds.), Communications: The Next Decade (London: Ofcom, 2006), pp. 41-50.

Netanel, Neil W., 'Market Hierarchy and Copyright in Our System of Free Expression' (2000) 53 Vanderbilt Law Review 1879-1932.

Netanel, Neil W., 'Why Has Copyright Expanded? Analysis and Critique', in F. Macmillan (ed.), New Directions in Copyright Law, vol. 6 (Cheltenham: Edward Elgar, 2007), pp. 3-34.

Netanel, Neil W., 'The WIPO Development Agenda and Its Development Policy Context', in N. W. Netanel (ed.), The Development Agenda: Global Intellectual Property and Developing Countries (Oxford University Press, 2009), pp. 1-32.

Nwauche, E. S., 'African Countries' Access to Knowledge and the WIPO Digital Treaties' (2005) 8 The Journal of World Intellectual Property 361-382.

OECD, Participative Web: User-Created Content, DSTI/ICCP/IE(2006)7/FINAL, 12 April 2007.

O’Regan, Tom and Goldsmith, Ben, 'Emerging Global Ecologies of Production', in D. Harries (ed.), The New Media Book (London: British Film Institute Publishing, 2004), pp. 92-105.

Palfrey, John G., Jr. and Rogoyski, Robert, 'The Move to the Middle: The Enduring Threat of "Harmful" Speech to the End-to-End Principle' (2006) 21 Washington University Journal of Law and Policy 31-66.

Peng, Shin-yi, 'Trade in Telecommunications Services: Doha and Beyond' (2007) 41 Journal of World Trade 293-317. 
Poretti, Pietro, 'Waiting for Godot: Subsidy Disciplines in Services Trade', in M. Panizzon, N. Pohl and P. Sauvé (eds), GATS and the Regulation of International Trade in Services (Cambridge University Press, 2008), pp. 466-488.

Reichman, Jerome H. and Lewis, Tracy, 'Using Liability Rules to Stimulate Local Innovation in Developing Countries: Application to Traditional Knowledge', in K. E. Maskus and J. H. Reichman (eds.), International Public Goods and Transfer of Technology under a Globalized Property Regime (Cambridge University Press, 2005), pp. 337-366.

Rosen, Jeffrey, ‘Google’s Gatekeepers', New York Times, 30 November 2008.

Roy, Martin, 'Audiovisual Services in the Doha Round: Dialogue de Sourds, The Sequel?' (2005) 6 Journal of World Investment and Trade 923-952.

Ruiz Fabri, Hélène, 'Reflections on Possible Future Legal Implications of the Convention', in N. Obuljen and J. Smiers (eds.), UNESCO's Convention on the Protection and Promotion of the Diversity of Cultural Expressions: Making It Work (Zagreb: Institute for International Relations, 2006), pp. 73-87.

Sauvé, Pierre and Steinfatt, Karsten, 'Towards Multilateral Rules on Trade and Culture: Protective Regulation or Efficient Protection?', in Productivity Commission and Australian National University, Achieving Better Regulation of Services (Canberra: AusInfo, 2000), pp. 323-346.

Sauvé, Pierre, 'Completing the GATS Framework: Addressing Uruguay Round Leftovers' (2002) 3 Aussenwirtschaft 301-341.

Sauvé, Pierre, 'Been There, Not Yet Done That: Lessons and Challenges in Services Trade', in M. Panizzon, N. Pohl and P. Sauvé (eds.), GATS and the Regulation of International Trade in Services (Cambridge University Press, 2008), pp. 599-631.

Singh, J. P., 'Culture or Commerce? A Comparative Assessment of International Interactions and Developing Countries at UNESCO, WTO, and Beyond' (2007) 8 International Studies Perspectives 36-53.

Sklar, Robert, Film: An International History of the Medium (Upper Saddle River, NJ: Prentice Hall, 1993).

Steiner, Thomas, 'Online Games under WTO Law: Unresolved Classification Issues' (2009) NCCR Trade Regulation Working Paper 2009/3.

Vaidhyanathan, Siva, 'The Googlization of Everything and the Future of Copyright' (2007) 40 UC Davis Law Review 1207-1231.

Vaidhyanathan, Siva, Copyrights and Copywrongs: The Rise of Intellectual Property and How It Threatens Creativity (New York University Press, 2003).

Weinberger, David, Everything Is Miscellaneous (New York: Henry Holt, 2007).

Wendland, Wend B., "It's a Small World (after all)": Some Reflections on Intellectual Property and Traditional Cultural Expressions', in C. B. Graber and M. Burri-Nenova (eds.), Intellectual Property and Traditional Cultural Expressions in a Digital Environment (Cheltenham: Edward Elgar, 2008), pp. 150-181. 
Wu, Tim, 'Network Neutrality, Broadband Discrimination' (2003) 2 Journal on Telecommunications and High Technology Law 141-174.

Wunsch-Vincent, Sacha, The WTO, the Internet and Trade in Digital Products (Oxford: Hart, 2006).

Yu, Dayong, 'The Harmonised System: Amendments and Their Impact on WTO Members' Schedules' (2008) WTO Economic Research and Statistics Division Staff Working Paper No. 2. 